Article

\title{
An Economic Analysis of Tropical Forest Resource Conservation in a Protected Area
}

\author{
Noel Perceval Assogba *(D) and Daowei Zhang \\ School of Forestry and Wildlife Sciences, Auburn University, Auburn, Alabama, AL 36849, USA; \\ zhangd1@auburn.edu \\ * Correspondence: npa0004@auburn.edu
}

Received: 13 June 2020; Accepted: 19 July 2020; Published: 21 July 2020

\begin{abstract}
In this paper, we develop a reduced form model for factors influencing the conservation of forest resources. We then estimate it using a bivariate negative binomial regression model with cases of illegal farming and illegal cattle grazing in the W Reserve in West Africa. Our results show that population size and farm area in the periphery of the $\mathrm{W}$ Reserve are associated with an increase of $2.4 \%$ and $7.1 \%$ of the illegal farming, respectively. On the other hand, income level, the existence of a checkpoint, and the distance between the villages and the reserve decrease the illegal grazing activities by $7.3 \%, 63.2 \%$, and $2.3 \%$, respectively.
\end{abstract}

Keywords: W Reserve; West Africa; illegal farming; illegal cattle grazing; protected area

\section{Introduction}

The conservation of tropical forest resources is vital because they provide $25 \%$ of our medicines worldwide and account for over $50 \%$ of the planet's biodiversity, although they only cover less than $10 \%$ of the earth [1]. They sustain millions of people worldwide and contribute directly and indirectly to countries' economies. Despite their importance, the conservation of tropical forest resources is still lacking [2]. The degradation of these resources not only reduces the world genetic diversity and its carbon sequestration capacity but also puts at risk scientific progress and discoveries in the areas of medicine and pest controls [3]. Hence, understanding the factors that influence their conservation is critical in designing effective policies to reduce their degradation.

The objective of this study is to investigate the effect of the characteristics of villages in the periphery of a protected area in tropical regions on its degradation. This is important for several reasons. First, forest degradation is most persistent in tropical regions [4]. Second, some forest resources in tropical regions are conserved as protected areas dedicated for the maintenance of biological diversity [5]. Third, in these regions, villages represent the basic administrative units in the periphery of protected areas [6].

In the literature, the conservation of tropical forest resources has been extensively investigated. For example, Geist and Lambin [7] investigated the proximate causes and underlying forces of tropical deforestation as reported in 152 subnational studies. The results suggest that economic, technological, and institutional factors are the main causes of tropical forest degradation. Furthermore, while agriculture expansion is identified as the major proximate cause for forest cover loss across all tropical regions, wood extraction and infrastructure expansions are region-specific. In contrast, using evidence from 118 studies on protected areas in Africa, Bowker et al. [8] identified protected areas' locations, accessibility, and sizes as the key factors determining forest cover loss within their boundaries. In Latin America, Culas [9] observed that cattle ranching represents a major factor in forest degradation. In Malawi, Ngwira and Watanabe [10] used interviews and focus groups to analyze the underlying factors associated with agriculture expansion as the major proximate cause of deforestation. The results 
suggest that population growth, poverty, and the market system are the underlying factors. In Uganda, L'Roe and Naughton-Treves [11] documented land-use change in the periphery of Kibale National Park, suggesting that market and infrastructures play a key role in the observed land-use change. These studies show that the factors influencing forest degradation in the tropics are diverse and vary within regions and countries.

In addition, several authors reported the complementarity and/or substitutability relationship between factors associated with tropical forest degradation. For example, at a global scale, Culas [12] (p. 16) noted that roundwood consumption, forest products exports, demand for cropland, and pasture are complementary in determining forest degradation. Similar observations are reported by Gieist and Lambin [7] (p. 143). However, few economic and empirical models of forest conservation explicitly account for this relationship in their analysis of the factors influencing forest degradation. For example, Perge and McKay [13], Pounfoun et al. [14], Babigumira et al. [15], Foster et al. [16], Godoy et al. [17], and Jones et al. [18] used the size of forest area cleared by households as the indicator of forest degradation in their studies. Diarrassouba and Boubacar [19] used the rate of forest loss as a proxy for forest degradation. Pichon [20] and Munoz [21] used the percentage of farmland in forest as the measurement of forest degradation.

The present study complements the existing literature by analyzing the characteristics of nearby villages in relation to the conservation of the $\mathrm{W}$ Reserve in West Africa. It uses both illegal farming and illegal cattle grazing as a proxy for the reserve degradation. The combination of more than one forest degradation attribute allows for accounting for possible complementarity and/or substitutability among the causes of forest resource degradation. Previous studies on the W Reserve and its periphery focused primarily on the biodiversity of the reserve (e.g., [22-28]) and land cover change in the periphery of the reserve (e.g., [29]).

The analysis proceeds as follows. In Section 2, we develop a theoretical model useful to understand the relationship between the characteristics of villages in the periphery of a protected area and its degradation. This is followed by an econometric model. Section 3 presents the study area and the data. The results of the paper are presented and discussed in Section 4. The paper concludes with a summary of key findings and policy implications.

\section{Model}

\subsection{Demand and Supply}

The demand and supply framework has been used in the literature to explain economic agents' behavior in the areas of agricultural economics (e.g., [30-34]), education economics (e.g., [35]), environmental economics (e.g., [36]), and forest economics (e.g., [37-39]). The framework has several strengths: it is fundamentally consistent with socioeconomic theory and it can characterize markets and generate relevant hypotheses. In this paper, we use this framework to analyze the relationship between the periphery of a protected area and its conservation.

Suppose that a protected area produces two aggregate goods, namely ecosystem goods (e.g., recreation, biodiversity) and non-ecosystem goods. Particularly, let us assume the non-ecosystem goods include fertile lands and fodder that are of interest for farmers and cattle ranchers nearby. Farmers and/or cattle ranchers demand the non-ecosystem goods as an input to produce farm products and cattle. Suppose these non-ecosystem goods can be priced $\left(P_{g}\right)$ with a demand function that depends on its own price $\left(P_{g}\right)$, and demand shift variables such as population size $(\bar{x})$, income $(\bar{m})$, institutions $(I)$ in the periphery of the protected area, and the distance $(\bar{d})$. Hence, the demand function can be expressed as follows:

$$
Q_{d}=Q_{d}\left(P_{g}, \bar{x}, \bar{m}, I, \bar{d}\right)
$$

The demand function is assumed to be a decreasing function of its own price $\left(\partial Q_{d} / \partial P_{g}<0\right)$, the income level $\left(\partial Q_{d} / \partial \bar{m}<0\right)$, institutions $\left(\partial Q_{d} / \partial I<0\right)$, and the distance between the protected area 
and the villages in its periphery $\left(\partial Q_{d} / \partial \bar{d}<0\right)$. The demand of the goods increases with the population size $\left(\partial Q_{d} / \partial \bar{x}<0\right)$.

As the institutions in the periphery of the protected area include checkpoints and non-governmental organizations, the institutions production function can be represented as follows:

$$
I=I(\bar{c}, \bar{z})
$$

The institutions are increasing function of the checkpoints $\left(\partial Q_{d} / \partial \bar{c}>0\right)$ and non-governmental organizations $\left(\partial Q_{d} / \partial \bar{z}>0\right)$.

The supply function of the good depends on its own price and is assumed upward sloping:

$$
Q_{s}=Q\left(P_{g}\right) \quad\left(\partial Q_{s} / \partial P_{g}>0\right)
$$

The market clearing condition below completes the model:

$$
Q_{s}=Q_{d}=Q
$$

The model above comprises 3 endogenous variables $Q, P_{g}, I$ and 5 exogenous variables $\bar{x}, \bar{m}, \bar{d}$, $\bar{c}, \bar{z}$.

Of key interest is the effect of the exogenous variables on the quantity of the non-ecosystem goods removed from the protected area. To this end, we first write Equations (1)-(4) in proportionate changes:

$$
\begin{gathered}
Q_{d}^{*}=\eta P_{g}^{*}+\eta_{x} \bar{x}^{*}+\eta_{m} \bar{m}^{*}+\eta_{I} I^{*}+\eta_{d} \vec{d}^{*} \eta<0, \eta_{x}>0, \eta_{I}<0, \eta_{m}<0, \eta_{d}<0 \\
I^{*}=\alpha_{c} \vec{c}^{*}+\alpha_{z} \bar{z}^{*} \quad \alpha_{c}>0, \alpha_{z}>0 \\
Q_{s}^{*}=\varepsilon P_{g}^{*} \varepsilon>0 \\
Q_{d}^{*}=Q_{s}^{*}=Q^{*}
\end{gathered}
$$

The asterisk (*) indicates proportionate change (e.g., $\left.Q_{j}^{*}=d Q_{j} / Q_{j}\right) ; \eta$ and $\varepsilon$ are the own-price elasticity of demand and supply for the non-ecosystem goods, respectively. $\eta_{x}, \eta_{m}, \eta_{I}, \eta_{d}$ are the elasticities of demand for the non-ecosystem goods with respect to population size, income, institutions, and distance, respectively. $\alpha_{c}, \alpha_{z}$ are the elasticities of the institutions with respect to checkpoints and non-governmental organizations in the periphery of the protected area. Next, we substitute Equation $\left(2^{\prime}\right)$ into $\left(1^{\prime}\right)$ and solve the reduced form model for price using Equation $\left(4^{\prime}\right)$ :

$$
P_{g}^{*}=\frac{\eta_{x}}{\varepsilon-\eta} \bar{x}^{*}+\frac{\eta_{m}}{\varepsilon-\eta} \bar{m}^{*}+\frac{\gamma_{c}}{\varepsilon-\eta} \bar{c}^{*}+\frac{\gamma_{z}}{\varepsilon-\eta} \bar{z}^{*}+\frac{\eta_{d}}{\varepsilon-\eta} \bar{d}^{*}
$$

where $\gamma_{c}=\eta_{I} \alpha_{c}, \gamma_{z}=\eta_{I} \alpha_{z}$.

Finally, the reduced form model for quantity is obtained by substituting (5) back into (3'):

$$
Q^{*}=\omega_{x} \vec{x}^{*}+\omega_{m} \bar{m}^{*}+\omega_{c} \vec{c}^{*}+\omega_{z} \bar{z}^{*}+\omega_{d} \vec{d}^{*}
$$

where $\omega_{x}=\frac{\varepsilon \eta_{x}}{\varepsilon-\eta}>0, \omega_{m}=\frac{\varepsilon \eta_{m}}{\varepsilon-\eta}<0, \omega_{c}=\frac{\varepsilon \gamma_{c}}{\varepsilon-\eta}<0, \omega_{z}=\frac{\varepsilon \gamma_{z}}{\varepsilon-\eta}<0, \omega_{d}=\frac{\varepsilon \eta_{d}}{\varepsilon-\eta}<0$.

Equation (6) suggests that an increase in population size increases the equilibrium quantity of the good removed from the protected area. On the other hand, an increase in the income level in the periphery of the protected area decreases the equilibrium quantity of the good removed from the protected area. Similarly, the existence of checkpoints and non-governmental organizations in the periphery of the protected area decreases the equilibrium quantity of the good removed from the protected area. Finally, an increase in the distance between the protected area and its periphery decreases the equilibrium quantity of the good removed from the protected area. 


\subsection{Bivariate Negative Binomial Regression (BNBR) Model}

In general, the elasticities in a reduced form equation are computed using the structural elasticities when they are available $[40,41]$. In the absence of the structural elasticities, the estimation of the reduced form Equation (6) of interest using the data can be used as an alternative.

In this study, we measured the W Reserve degradation using count data, namely, the number of cases of illegal farming and illegal cattle grazing. For count data, several models could be used (e.g., Poisson, negative binomial) [42]. Particularly, while Poisson model is recommended when the data meet the equidispersion assumption, the negative binomial model is appropriate when the data meets the overdispersion condition $[43,44]$. Table 1 presents the results of the test of overdispersion on the response variables (illegal farming and illegal cattle grazing), suggesting the negative binomial model as appropriate regression model.

Table 1. Test of overdispersion on the response variables.

\begin{tabular}{cccc}
\hline$\hat{\mu}$ & Coefficient & Standard Error & $\boldsymbol{p}$-Value \\
\hline illegal farming & 2.6441 & 0.8941 & 0.004 \\
illegal cattle grazing & 1.3464 & 0.2994 & 0.000 \\
\hline
\end{tabular}

Illegal activity cases such as illegal farming and illegal cattle grazing in the protected area may be correlated within village $i$ because individuals can be involved in both illegal activities. To account for this correlation between both types of illegal activities, the bivariate negative binomial regression model can be appropriately used as a more efficient regression model to identify the factors determining these activities [42,45]. Furthermore, the model gains in efficiency over a univariate negative binomial regression by considering cross-equation correlations. In the literature, several authors have used the bivariate negative binomial regression model to analyze correlated count-dependent variables (e.g., $[44,46])$.

Following references $[44,45]$, the joint density function of the bivariate negative binomial model can be specified as follows:

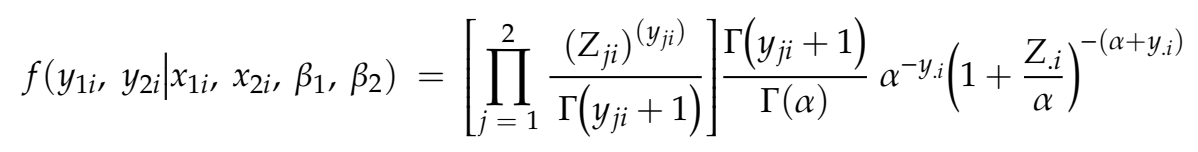

where:

$y_{j}$ is the $j$ response variable with $j=$ \{number of cases of illegal farming, number of cases of illegal cattle grazing $\} ; Z_{j i}=\exp \left(x_{j i}^{\prime} \beta_{j}\right)=E\left(y_{j i} \mid x_{j i}\right)$ is the conditional mean parameter associated with the $j$ response variable for village $i ; y_{. i}=\sum_{j=1}^{2} y_{j i} ; Z_{. i}=\sum_{j=1}^{2} Z_{j i} . x_{j i}$ is a $\left(k_{j} \times 1\right)$ vector of covariates; and $\beta_{j}$ a $\left(k_{j} \times 1\right)$ vector of unknown parameters. In addition to the variables defined in the theoretical model, the variables cash crop and farm area are included in the illegal farming equation to account for their effect on illegal farming activities [47]. Table 2 presents the definition of the variables used to estimate the bivariate negative binomial model. 
Table 2. Variables definition.

\begin{tabular}{cc}
\hline Variables & Description \\
\hline illegal farming & Illegal farming (number of cases) \\
illegal cattle grazing & Illegal cattle grazing (number of cases) \\
population & Population divided by 1000 \\
income & Income divided by 100 (in West African CFA) \\
farm area & Farm area (in hectares) \\
cash crop & Cash crop = 1 if yes; 0 otherwise \\
env_ngo & Environmental non-governmental organization \\
financial institutions & Number of financial institutions \\
checkpoints & Checkpoint = 1 if yes; 0 otherwise \\
distance & Distance (in kilometers) \\
\hline
\end{tabular}

\section{Study Area and Data}

The $\mathrm{W}$ Reserve was chosen as the study area because it is one of the largest reserves in West Africa and crosses three countries, namely Benin, Burkina Faso, and Niger with a wide range of villages in its periphery. Covering an area of 1,024,280 hectares with 563,280 hectares in Benin; 235,000 hectares in Burkina Faso; and 226,000 hectares in Niger, the W Reserve is located between $11^{\circ}$ and $12^{\circ} 35$ north latitude and $2^{\circ}$ and $3^{\circ} 50$ east longitude [26].

The fauna in the $\mathrm{W}$ Reserve is one of the richest on the continent and includes emblematic species such as lions (Panthera leo), giraffes (Giraffa camelopardalis), gazelles (Gazella rufifrons), Buffon's kobs (Kobu kob), and reptiles [27]. Moreover, it is one of the rare places in Africa where endangered species such as cheetahs, wild African dogs, and African elephants are living. Its vegetation comprises savannah, gallery forests, and grasslands.

The periphery of the $\mathrm{W}$ Reserve comprises about 210 villages with a human population estimated at 405,000 [48]. This population belongs to different ethnic groups who share several ties and cultures. Particularly, the population in the periphery of the reserve has a long history of relationships with their natural environment with farming, hunting, cattle grazing, and wood and non-wood resources as their main source of livelihood. Although there are collaborations and concertation in the management principles of the reserve, each country managed the areas of the reserve on its territory based on its national legislation. Figure 1 presents the study area.

Data used in the identification of factors influencing the degradation of the $\mathrm{W}$ Reserve cover the period January 2016 to May 2017. Data on illegal farming and illegal cattle grazing were obtained from the reserve surveillance administrations in Benin, Burkina Faso, and Niger. Illegal farming refers to any encroachment and/or land clearing within the reserve limits for farming while illegal cattle grazing refers to any grazing by domestic cattle in the reserve. These statistics were compiled by the reserve administrations in all three countries during their surveillance patrols. The socioeconomics and institutional characteristics of 93 villages in the periphery of the W Reserve were obtained and used for the study. Particularly, the average income level, population, number of financial institutions, and number of non-governmental organizations promoting nature preservation were obtained from the administrations of the municipalities in the periphery of the reserve. Finally, the data on the existence of checkpoints, and the distance between the reserve and the villages were obtained from the W Reserve administrations in the three countries.

Table 3 presents the summary statistics on the number of cases of illegal farming and illegal cattle grazing recorded by the reserve surveillance administrations in the three countries during the period January 2016 to May 2017. Illegal cattle grazing was the most important case of infraction recorded. The predominance of illegal cattle grazing cases could be explained by the importance of cattle in the economy of local communities, and the extensive mode of animal husbandry in place in the region. Natural fodders and water streams being the main source of food and water for the livestock, the W Reserve, due to its abundant resources of plants and water resources (e.g., Niger River), represented an ideal place for grazing. 


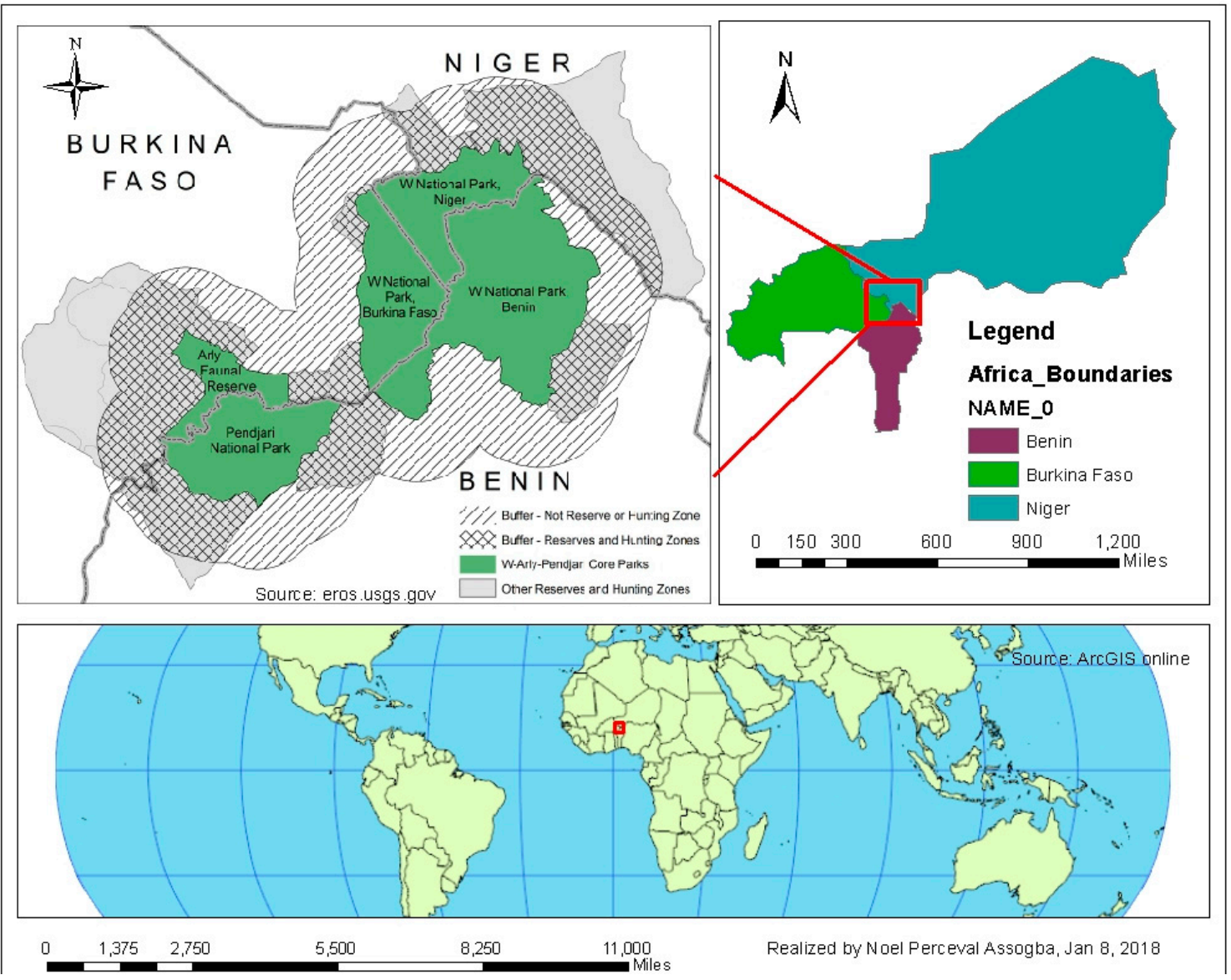

Figure 1. Study area.

Table 3. Socioeconomics and institutional characteristics of the villages in the periphery of the W Reserve.

\begin{tabular}{ccccc}
\hline Variables & Mean & Std. Dev. & Min & Max \\
\hline illegal farming & 0.3763 & 0.8712 & 0 & 4 \\
illegal cattle grazing & 1.7312 & 2.4143 & 0 & 9 \\
population & 1577.2350 & 1679.4870 & 55 & 10,315 \\
income & $16,715.0500$ & 6440.9520 & 10,000 & 30,000 \\
farm area & 2.1411 & 1.0880 & 1 & 4 \\
financial institutions & 1.0430 & 0.8200 & 0 & 2 \\
env_ngo & 1.2043 & 0.7598 & 0 & 2 \\
distance & 15.3180 & 16.0764 & 0 & 66.3843 \\
\hline
\end{tabular}

The number of infractions was unevenly distributed across the three countries. While the cases of illegal farming (35) in the reserve were only recorded in Benin, illegal cattle grazing cases (161) were observed in the three countries. Figure 2 presents the distribution of cattle grazing cases in the region. The highest number of illegal cattle grazing cases were recorded in Benin, representing 55\% of the total number of cases followed by Burkina Faso with $29 \%$ of the cases. The lowest number was recorded in Niger, $16 \%$. Note that the average distance between the villages and the reserve was estimated at 15.32 kilometers. 


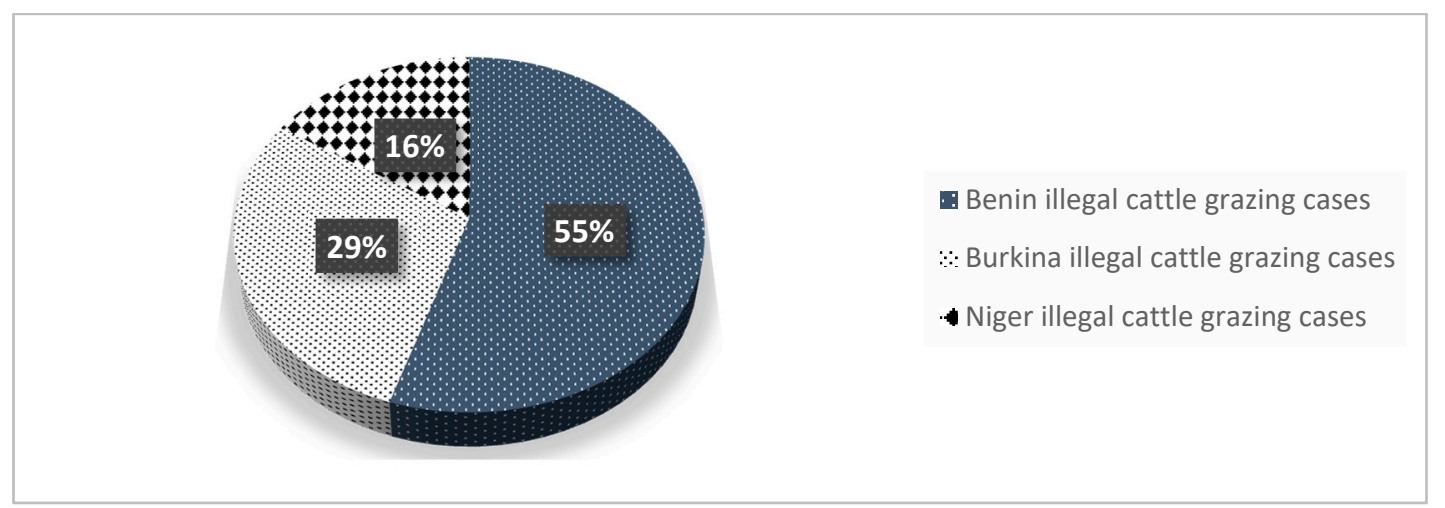

Figure 2. Repartition of number of cases of illegal cattle grazing in the region.

\section{Results and Discussion}

The bivariate negative binomial regression estimation results are presented in Table 4. Model 1 and Model 2 in Table 4 are similar with the exception that country fixed effects are included in Model 2. The Wald test of overall significance is statistically significant in both models ( $p$-value $=0.0001$, $p$-value $=0.0016)$, suggesting that the models are globally significant. The results in Model 1 suggest that the characteristics of the villages in the periphery of the reserve, namely, population size, average income, average farm areas, the existence of check points, and distance influence its degradation.

Table 4. Negative binomial estimation results of factors influencing the $\mathrm{W}$ Reserve degradation.

\begin{tabular}{|c|c|c|c|c|}
\hline \multirow{2}{*}{ Variables } & \multicolumn{2}{|l|}{ Model 1} & \multicolumn{2}{|l|}{ Model 2} \\
\hline & Illegal Farming & Illegal Cattle grazing & Illegal Farming & Illegal Cattle Grazing \\
\hline \multicolumn{5}{|c|}{ Socioeconomic characteristics } \\
\hline \multirow[t]{2}{*}{ population } & 0.0237 * & 0.0122 & 0.0129 & 0.0122 \\
\hline & $(0.0144)$ & $(0.0090)$ & $(0.0130)$ & $(0.0094)$ \\
\hline \multirow[t]{2}{*}{ income } & 0.0210 & $-0.0729 *$ & 0.0506 & $-0.0740 *$ \\
\hline & $(0.0581)$ & $(0.0387)$ & $(0.0503)$ & $(0.0391)$ \\
\hline \multirow[t]{2}{*}{ farm area } & $0.0713^{* *}$ & - & 0.0295 & - \\
\hline & $(0.0305)$ & - & $(0.0260)$ & - \\
\hline \multirow[t]{2}{*}{ cash crop } & 0.2821 & - & 0.7114 & - \\
\hline & $(0.6312)$ & - & $(0.5283)$ & - \\
\hline \multicolumn{5}{|l|}{ Institutions } \\
\hline \multirow[t]{2}{*}{ financial institutions } & -0.2837 & 0.1904 & -0.3987 & 0.2094 \\
\hline & $(0.4316)$ & $(0.2447)$ & $(0.3865)$ & $(0.2551)$ \\
\hline \multirow[t]{2}{*}{ env_ngo } & -0.0296 & 0.2758 & -0.2823 & 0.2681 \\
\hline & $(0.6896)$ & $(0.2329)$ & $(0.3954)$ & $(0.2755)$ \\
\hline \multirow[t]{2}{*}{ checkpoints } & -0.8157 & $-0.6324 *$ & -0.7669 & $-0.6624^{*}$ \\
\hline & $(0.7236)$ & $(0.3703)$ & $(0.6188)$ & $(0.3865)$ \\
\hline \multicolumn{5}{|l|}{ Location } \\
\hline \multirow[t]{2}{*}{ distance } & -0.0296 & $-0.0225 *$ & $-0.0346^{* *}$ & -0.0234 \\
\hline & $(0.0200)$ & $(0.0136)$ & $(0.0166)$ & $(0.0142)$ \\
\hline Country Fixed Effect & No & No & Yes & Yes \\
\hline \multirow[t]{2}{*}{ Constant } & $-2.6000 * * *$ & $1.3895^{* * *}$ & $-1.6800 * *$ & $1.4079 * *$ \\
\hline & $(0.9001)$ & $(0.5644)$ & $(0.7682)$ & $(0.5707)$ \\
\hline Observations & 93 & 93 & 93 & 93 \\
\hline Wald chi2 & \multicolumn{2}{|r|}{43.5600} & \multicolumn{2}{|r|}{40.9400} \\
\hline$p$-value & \multicolumn{2}{|r|}{0.0001} & \multicolumn{2}{|r|}{0.0016} \\
\hline LR chi2 & \multicolumn{2}{|r|}{54.3400} & \multicolumn{2}{|r|}{55.4600} \\
\hline$p$-value & \multicolumn{2}{|r|}{0.0000} & \multicolumn{2}{|r|}{0.0000} \\
\hline
\end{tabular}

Particularly, the variables determining illegal farming activities in the reserve in Model 1 are the population size and farm area. These variables are statistically significant at the $10 \%$ and $5 \%$ levels, respectively. The sign of the coefficients of both variables is positive and consistent with theory. While an increase in the population size of one unit is associated with an increase in the number of 
cases of illegal farming by $2.4 \%$, an increase in the average farm areas by one unit is associated with an increase in the number of cases of illegal farming by $7.1 \%$.

The positive effect of population size on illegal farming cases could be explained by the fact that a higher population increases the competition for land, making the $\mathrm{W}$ Reserve attractive. This result is consistent with the results of Foster et al. [16] who observed a positive relationship between population and the reduction of forest areas in India. Similar relationships between population and forest degradation are also found in Nepal, Thailand, and at a global scale [49-51]. Similarly, the positive effect of the average farm area in the villages with the number of cases of illegal farming could be explained by the farming system in the region. Farming in the region is still traditional with low use of technology and inputs such as fertilizers. Hence, farmers, to increase the production of their farms, could find the W Reserve fertile lands attractive. This result is also consistent with the findings of Angelsen [52] in subsistence economies with low levels of agricultural productivity.

In contrast, three variables determine illegal cattle grazing in the reserve, namely, the average income level, the existence of checkpoints, and the distance between the villages and the reserve. These variables are statistically significant at the $10 \%$ significance level. The sign of the coefficients of these variables is negative and consistent with theory. Particularly, an increase in the average income level of one unit is associated with a decrease in the number of cases of cattle ranching by $7.3 \%$. Similarly, while the existence of checkpoint between the reserve and the villages in its periphery decreases the number of cases of illegal cattle grazing by $63.2 \%$, an increase in the distance by one unit is associated with a decrease in the number of cases of illegal cattle ranching by $2.3 \%$.

The negative effect of the existence of checkpoints on illegal cattle grazing could be explained by the increase in the private costs of (illegal) cattle ranchers. The existence of checkpoints raises the risks for the (illegal) cattle ranchers to be caught by the reserve surveillance units and face the penalties such as fines and/or jails. This is also consistent with the results of Borner et al. [53], Lober [54], Gibson et al. [55], and Bruner et al. [56] who identified enforcement as an effective conservation instrument. Similarly, the negative effect of distance on illegal cattle grazing cases may suggest that when the distance between the reserve and the villages in its periphery increases, herders may resort to other places closer for grazing. However, the negative effect of the average income level on illegal cattle grazing could suggest that cattle ranching activities are income-generating activities of low-income level individuals.

\section{Conclusions}

This paper contributes to the existing literature on forest resource conservation in several ways. First, it accounts for the relationship between forest degradation activities such as illegal farming and illegal cattle grazing in a protected area. Second, we developed a reduced form model using demand and supply framework to analyze the effects of the periphery of the W Reserve on its degradation. Our results are consistent with theory and other empirical results that socioeconomics, institutions, and locational characteristics of the villages in the periphery of forest resource or protected areas influence their degradation. Particularly, we find that population size and farm area increase the illegal farming activities in the reserve degradation while the average income level, the existence of checkpoints, and distance decrease its degradation in terms of illegal grazing.

As policy implication, the findings in this paper suggest that the characteristics of villages in the periphery of a protected area play a critical role in its conservation. For better preservation and conservation of tropical forest resources in general, and in particular the W Reserve, significant emphasis should be put on improving the socioeconomic and institutional setting in the villages closer to the reserve as well as the farming system. The installation of checkpoints and the promotion of policy aiming at improving farm performances in the area could be effective policies to reduce the pressure faced by the reserve if and when the marginal costs associated with the investments are less than the marginal benefits associated with the reserve conservation. Further, policies aiming at improving the average income level in the villages in the periphery of the reserve could have a positive 
effect on the preservation of the reserve. These are some concrete measures that should be taken first to reduce the anthropogenic pressure on the reserve. As a final note, it should be pointed out that the results of this study need to be interpreted with caution because we used reported data for illegal activities as our dependent variable, and in cases where the illegal cattle grazers and/or farmers are not apprehended, they would not be reported.

Author Contributions: Conceptualization, D.Z. and N.P.A.; Methodology, D.Z. and N.P.A.; Validation, D.Z.; Data curation, N.P.A.; Writing-original draft preparation, N.P.A. and D.Z.; Writing-review and editing, N.P.A. and D.Z.; Supervision, D.Z.; and Funding acquisition, D.Z. All authors have read and agreed to the published version of the manuscript.

Funding: This project is supported by Auburn University.

Acknowledgments: We thank Auburn University for providing funding support. We are also grateful to the administrations of the W Reserve in Benin, Burkina Faso, and Niger for the provision of some of the data used in the study; the municipalities in the periphery of the Reserve; and two anonymous reviewers for comments on a previous draft.

Conflicts of Interest: The authors declare no conflict of interest.

\section{References}

1. Lasco, R.D. Tropical Forests and Climate Change Mitigation: The Global Potential and Cases from the Philippines. Asian J. Agric. Rural Dev. 2008, 5, 18.

2. MacDicken, K.; Jonsson, Ö.; Piña, L.; Maulo, S.; Contessa, V.; Adikari, Y.; Garzuglia, M.; Lindquist, E.; Reams, G.; D'Annunzio, R. Global Forest Resources Assessment 2015: How Are the World's Forests Changing? 2nd ed.; Food Agriculture Organization: Rome, Italy, 2016; pp. 1-54.

3. Deacon, R.T. Assessing the Relationship between Government Policy and Deforestation. J. Environ. Econ. Manag. 1995, 28, 1-18. [CrossRef]

4. Keenan, R.; Reams, G.A.; Achard, F.; De Freitas, J.V.; Grainger, A.; Lindquist, E. Dynamics of global forest area: Results from the FAO Global Forest Resources Assessment 2015. For. Ecol. Manag. 2015, 352, 9-20. [CrossRef]

5. Economic Values of Protected Areas. 1998. Available online: https://portals.iucn.org/library/efiles/documents/ PAG-002.pdf (accessed on 16 August 2019).

6. Foster, A.D.; Rosenzweig, M.R.; Behrman, J.R. Population, Income and Forest Growth: Management of Village Common land in India. 2011. Available online: https://pdfs.semanticscholar.org/f322/ 5d61dd434061c1892111fcdf8b24e2512c90.pdf (accessed on 13 December 2019).

7. Geist, H.J.; Lambin, E.F. Proximate Causes and Underlying Driving Forces of Tropical Deforestation Tropical forests are disappearing as the result of many pressures, both local and regional, acting in various combinations in different geographical locations. BioScience 2002, 52, 143-150. [CrossRef]

8. Bowker, J.N.; De Vos, A.; Ament, J.M.; Cumming, G.S. Effectiveness of Africa's tropical protected areas for maintaining forest cover. Conserv. Biol. 2017, 31, 559-569. [CrossRef] [PubMed]

9. Culas, R.J. The Causes and Consequences of Tropical Deforestation: A Review. Int. J. Clim. Chang. Impacts Responses 2009, 1, 127-140. [CrossRef]

10. Ngwira, S.; Watanabe, T. An Analysis of the Causes of Deforestation in Malawi: A Case of Mwazisi. Land 2019, 8, 48. [CrossRef]

11. L'Roe, J.; Naughton-Treves, L. Forest edges in western Uganda: From refuge for the poor to zone of investment. For. Policy Econ. 2017, 84, 102-111. [CrossRef]

12. Culas, R.J. Causes of Deforestation and Policies for Reduced Emissions (REDD+): A Cross-country Analysis. IUP J. Appl. Econ. 2014, 13, 7.

13. Perge, E.; McKay, A. Forest clearing, livelihood strategies and welfare: Evidence from the Tsimane' in Bolivia. Ecol. Econ. 2016, 126, 112-124. [CrossRef]

14. Poufoun, J.N.; Guillot, S.C.; Delacote, P. Households Livelihoods and Deforestation in the Tridom Transboundary Conservation: A Spatial Analysis. 2016. Available online: https://www6.nancy.inrae. fr/lef/content/download/4533/55067/version/2/file/Cahier+du+LEF+2016-06.pdf (accessed on 19 July 2019).

15. Babigumira, R.; Angelsen, A.; Buis, M.; Bauch, S.; Sunderland, T.; Wunder, S. Forest Clearing in Rural Livelihoods: Household-Level Global-Comparative Evidence. World Dev. 2014, 64, S67-S79. [CrossRef] 
16. Foster, A.D.; Rosenzweig, M.R.; Behrman, J.R. Population Growth, Income Growth, and Deforestation: Management of Village Common Landin India; Brown University, Rhode Island and University of Pennsylvania: Philadelphia, Mimeo, 1997.

17. Godoy, R.; O’Neill, K.; Groff, S.; Kostishack, P.; Cubas, A.; Demmer, J.; McSweeney, K.; Overman, J.; Wilkie, D.; Brokaw, N.; et al. Household determinants of deforestation by amerindians in honduras. World Dev. 1997, 25, 977-987. [CrossRef]

18. Jones, D.W.; Dale, V.H.; Beauchamp, J.J.; Pedlowski, M.A.; O’Neill, R.V. Farming in Rondônia. Resour. Energy Econ. 1995, 17, 155-188. [CrossRef]

19. Diarrassouba, M.; Boubacar, I. Deforestation in Sub-Sahara Africa 2009. In Proceedings of the 2009 Annual Meeting, Atlanta, GA, USA, 31 January-3 February 2009.

20. Pichón, F.J. Colonist Land-Allocation Decisions, Land Use, and Deforestation in the Ecuadorian Amazon Frontier. Econ. Dev. Cult. Chang. 1997, 45, 707-744. [CrossRef]

21. Muñoz, P.C. Forest or No Forest: A Logit Model of Land Use in Mexico. Master's Thesis, Department of Economics, University College, London, UK, 1992.

22. Myrèse, C.A.; Mireille, S.T.; Dan, B.S.; Marcel, R.B.; Brice, S. Effects of land cover change on rangeland vegetation in W Biosphere Reserve, Benin Republic, West Africa. J. Res. For. Wildl. Environ. 2016, 8, 157-170.

23. Ipavec, A. Characteristics and Determinants of Elephant Population Spatial Distribution in the W Regional Park, West Africa. Ph.D. Thesis, Agrocampus Ouest, Rennes, France, 2012.

24. Assogba, N.P. Transhumance and Communal Management: Characterization of the Main Fodder Trees in the Cross-Border Lands of the W Biosphere Reserve. Master's Thesis, University of Parakou, Parakou, Benin, 2011.

25. Hibert, F. Déterminants Écologiques et Anthropiques de la Structuration des Peubplements D'ongulés Sauvages en Afrique de l'Ouest: Cas du Parc Régional du W du Fleuve Niger. Ph.D. Thesis, Agrocampus Ouest, Rennes, France, 2007.

26. Mahamane, A. Etudes floristique, phytosociologique et phytogéographique de la végétation du Parc Régional du W Niger. Acta Bot. Gall. 2006, 153, 265-269. [CrossRef]

27. Rabeil, T. Distribution Potentielle des Grands Mammifères Dans le Parc du W au Niger. Ph.D. Thesis, Université Paris-Diderot-Paris VII, Paris, France, 2003.

28. Clerici, N.; Bodini, A.; Eva, H.; Grégoire, J.-M.; Dulieu, D.; Paolini, C. Increased isolation of two Biosphere Reserves and surrounding protected areas (WAP ecological complex, West Africa). J. Nat. Conserv. 2007, 15, 26-40. [CrossRef]

29. Houessou, L.G.; Teka, O.; Imorou, I.T.; Lykke, A.M.; Sinsin, B. Land Use and Land-Cover Change at "W" Biosphere Reserve and Its Surroundings Areas in Benin Republic (West Africa). Environ. Nat. Resour. Res. 2013, 3, 87. [CrossRef]

30. Kinnucan, H.W.; Minh, N.D.; Zhang, D. Trade diversion and antidumping effectiveness: Insights from a residual demand model. Aust. J. Agric. Resour. Econ. 2017, 26, 159-340. [CrossRef]

31. Kinnucan, H.W.; Cai, H. A Benefit-Cost Analysis of U.S. Agricultural Trade Promotion. Am. J. Agric. Econ. 2011, 93, 194-208. [CrossRef]

32. Martin, W.; Anderson, K. Export Restrictions and Price Insulation during Commodity Price Booms. Am. J. Agric. Econ. 2011, 94, 422-427. [CrossRef]

33. Yu, R.; Leung, P. Estimating the economic benefits of area-wide pest management: An extended framework with transport cost. Ann. Reg. Sci. 2009, 46, 455-468. [CrossRef]

34. Beattie, B.R.; Alston, J.M.; Norton, G.W.; Pardey, P.G. Science under Scarcity: Principles and Practice for Agricultural Research Evaluation and Priority Setting. Ithaca NY: Cornell University Press, 1995, xxxiii +585 pp., cloth, price unknown. Am. J. Agric. Econ. 1995, 77, 1064-1065. [CrossRef]

35. Kinnucan, H.W.; Zheng, Y.; Brehmer, G. State Aid and Student Performance: A Supply-Demand Analysis. Educ. Econ. 2006, 14, 487-509. [CrossRef]

36. Nguyen, L.; Kinnucan, H.W. The US solar panel anti-dumping duties versus uniform tariff. Energy Policy 2019, 127, 523-532. [CrossRef]

37. Lin, Y.; Zhang, D. Incidence of Russian log export tax: A vertical log-lumber model. J. For. Econ. 2017, 29, 69-77. [CrossRef] 
38. Gao, L.; Kinnucan, H.W.; Zhang, Y.; Qiao, G. The effects of a subsidy for grassland protection on livestock numbers, grazing intensity, and herders' income in inner Mongolia. Land Use Policy 2016, 54, 302-312. [CrossRef]

39. Sun, C. Timber Market Recovery after a Hurricane. For. Sci. 2016, 62, 600-612. [CrossRef]

40. Piggott, R.R. Some Old Truths Revisited. Aust. J. Agric. Econ. 1992, 36, 117-140. [CrossRef]

41. Muth, R.F. The derived demand curve for a productive factor and the industry supply curve. Oxf. Econ. Pap. 1964, 16, 221-234. [CrossRef]

42. Cameron, A.C.; Trivedi, P.K. Microeconometrics Using Stata; Revised Edition; StataCorp: Brazos, TX, USA, 2010.

43. Winkelmann, R. Econometric Analysis of Count Data; Springer Science \& Business Media: Berlin, Germany, 2008.

44. Gurmu, S.; Elder, J. Generalized bivariate count data regression models. Econ. Lett. 2000, 68, 31-36. [CrossRef]

45. Chou, N.T.; Steenhard, D. Bivariate Count Data Regression Models-A SAS ${ }^{\circledR}$ Macro Program. Statistics and Data Analysis. 2011, p. 355. Available online: http://citeseerx.ist.psu.edu/viewdoc/download?doi=10.1.1. 353.4967\&rep=rep1\&type $=$ pdf (accessed on 16 August 2019).

46. Shi, P.; Valdez, E. Multivariate negative binomial models for insurance claim counts. Insur. Math. Econ. 2014, 55, 18-29. [CrossRef]

47. Barua, S.K.; Uusivuori, J.; Kuuluvainen, J. Impacts of carbon-based policy instruments and taxes on tropical deforestation. Ecol. Econ. 2012, 73, 211-219. [CrossRef]

48. ECOPAS. Dynamiques d'acteurs dans les Zones Peripheriques du Parc Regional du W: Conflictualite et Concertation. In Recherche sur les Aspects Socio-territoriaux dans les Zones Peripheriques du Parc Regional W Finalisee au Reperage de Criteres Pour le Zonage; Rapport Definitif, Programme Regional Parc W/ECOPAS: Ouagadougou, Burkina Faso, 2003.

49. Bhattarai, K.; Conway, D.; Yousef, M. Determinants of deforestation in Nepal's central development region. J. Environ. Manage. 2009, 91, 471-488. [CrossRef] [PubMed]

50. Cropper, M.L.; Griffiths, C.; Mani, M. Roads, Population Pressures, and Deforestation in Thailand, 1976-1989. Land Econ. 1999, 75, 58. [CrossRef]

51. Mather, A.S.; Needle, C.L. The relationships of population and forest trends. Geogr. J. 2000, 166, 2-13. [CrossRef]

52. Angelsen, A. Deforestation: Population or Market Driven? Different Approaches in Modelling Agricultural Expansion. Available online: https://open.cmi.no/cmi-xmlui/handle/11250/2435832 (accessed on 18 March 2020).

53. Börner, J.; Wunder, S.; Wertz-Kanounnikoff, S.; Hyman, G.; Nascimento, N. Forest law enforcement in the Brazilian Amazon: Costs and income effects. Glob. Environ. Chang. 2014, 29, 294-305. [CrossRef]

54. Lober, D.J. Using forest guards to protect a biological reserve in Costa Rica: One step towards linking parks to people. J. Environ. Plan. Manag. 1992, 35, 17-41. [CrossRef]

55. Gibson, C.C.; Williams, J.T.; Ostrom, E. Local Enforcement and Better Forests. World Dev. 2005, 33, $273-284$. [CrossRef]

56. Bruner, A.G.; Gullison, R.E.; Rice, R.E.; Da Fonseca, G.A. Effectiveness of Parks in Protecting Tropical Biodiversity. Science 2001, 291, 125-128. [CrossRef] [PubMed]

(C) 2020 by the authors. Licensee MDPI, Basel, Switzerland. This article is an open access article distributed under the terms and conditions of the Creative Commons Attribution (CC BY) license (http://creativecommons.org/licenses/by/4.0/). 